\title{
Product development
}

Switch off, tune out, and clean up.

\section{Nancy Kress}

“That's the stupidest idea I've ever seen," the vice-president for marketing said, but so softly that only his neighbour heard. "What is the Old Man thinking?"

"Dunno," VP Sales whispered back. "But he loves it. Look at him."

The chief executive of Veritronics Telecommunications smiled at the head of the vast teak table in the vast corporate boardroom. Beside him fidgeted the head of $R \& D$, a small pinch-faced man with the glowing maniacal eyes of a feverish gerbil. On R\&D's palm rested a black plastic cube, featureless except for a simple red toggle switch.

"This model affects an area of radius 20 feet, ${ }^{\text {, }}$ \&D said fervently, "but we plan to create a whole range of models to cover homes and facilities of different sizes, maybe even different shapes. It'll make Veritronics a fortune?"

"Demonstrate it for them, Lucius," the CEO said.

R\&D toggled the switch. Instantly the wall panels, which had been displaying a fractal composition by revered holoartist Cameron Mbutu, went dark. Every handheld in the room stopped functioning, marooning VP Accounting, who'd been surreptitiously playing Alien Attack, on level 184. All personal receivers ceased operation, cutting off VP Sales from the field reports reciting softly in her ear; VP Admin from the London Philharmonic's performance of Haydn's Symphony No. 104; and Veritronics' General Counsel from the weather report for Cancun, where he was going on holiday. All cell phones stopped vibrating in all pockets. In the middle of the immense table, the electronic news screen blanked, along with the second-by-second stock reports from six cities and the lunch menu. Only the lights and heat stayed on.

VP Marketing and VP Sales glanced at each other. VP Sales was braver.

"Sir...why do you think anyone would want to jam their own home telecommunications? And - with all due respect, sir - why would we want them to?"

The CEO smiled. "Lucius, show them the tape.

R\&D did something under the table. A single wall panel glowed. "This is a composite of the data from 146 beta-test trials. It has no margin of error."
A middle-dass living room. "Jimmy!" a harried woman screeched. "Did you do your homework? Jimmy! Alia, I told you to watch the baby! Paul, I need help here!"

Jimmy, oblivious, beat time on the sofa arm to his personal receiver. Alia hunched over a video game, her fingers flying. Paul spoke rapidly into his handheld. The baby tumbled down a short flight of steps, its wailing nearly lost in the TV blare.

The woman snatched up the screaming baby, glared at her family, and reached into her pocket. CLOSE-UP as she toggled a red switch on a

blackbox.

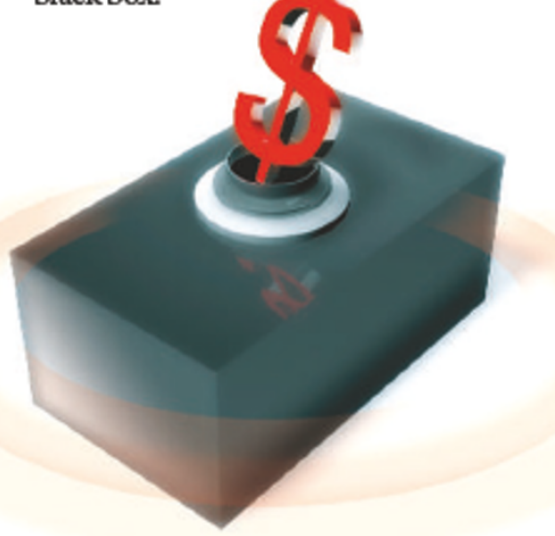

“Hey!" Jimmy cried. Alia continued to work her dead controls. Paul jumped up wildly. "Mia, what happened?"

"I don't know," Mia said innocently. ${ }^{\alpha}$ Must be a power outage."

“The lights are still on!"

${ }^{\alpha}$ Well...I don't know. I'll get cards and make popcorn, okay? ${ }^{x}$ She smiled quietly.

VP Sales whispered: ${ }^{\alpha}$ Told you so. The Old Man's lost it."

VP Marketing didn't reply. Sweat banded his forehead and he clenched his hands tightlybelow the table.

The screen flashed TWO HOURS LATER. The family sat slumped over a card game. Paul snapped: "Mia, I told you and told you to not trump my ace."

"Well, I'm sorry! If you didn't always ... Jimmy, stop kicking me! ${ }^{\text {" }}$

"I can't help it," Jimmy whined.

"You know he's ADD, " Paul said in disgust. "Why are you always riding him?"

"If you'd ever discipline him to..."

“I'm bored," Alia said. "And I'm s'posed to call Tara! It's important!"

“Tara can wait," Paul said.

"You never let me do anything! I wish I had different parents!"

Mia looked stricken. Paul said heatedly,
"You liked us well enough when we all went on that VR safari last month?"

"Yeah...but that was fun. Jimmy, stop kicking me!"

Jimmy threw his cards at Alia. Paul glared at Mia. "Great idea this was, genius!"

${ }^{\alpha}$ Don't start with me, Paul. I'm as smart as you are even if not everybody can go to Harvard."

Alia burst into tears, waking the baby.

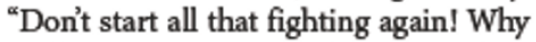
don't you two just get divorced! I hate you!" She stomped from the room. Paul followed, slamming the door. Jimmy slunk of under the table, kicking its legs. Mia looked around helplessly, then slipped her hand into her pocket.

"That's enough, Lucius," the CEO said. The wall went dark. ${ }^{\alpha}$ This family lasted two hours and three minutes before all their sublimated resentments and group tensions broke out. That's 16 minutes longer than average."

"But..." VP Sales began, then stopped. Her heart beat too hard and her left temple twitched.

"Within the next five hours," the

CEO continued, "this family purchased four new electronic products, two of them from Veritronics."

VP Marketing dug the nails of one hand into the flesh of the other. Sweat slimed his forehead: "No...no margin of error, sir?"

${ }^{\alpha}$ None. Every single test case exhibited the same behaviour."

"The same," croaked R\&D. His foot beat a ragged staccato on the floor.

${ }^{\alpha}$ Four new sales in five hours," General Counsel repeated. His face had paled to the unhealthy colour of sourdough.

The CEO toggled the red switch. Instantly the wall panels shone with gorgeous art. The table screens resumed their ceaseless supply of data. Haydn, Alien Attack and field reports all played. Cell phones vibrated. Handhelds glowed. There were 23 lunch options.

VP Marketing felt his breathing steady, his heart slow, his sweat evaporate. ${ }^{\alpha} \mathrm{I}$ propose accelerated development and launch of the Veritronics Home Electronic Jamming Saviour, sir. Put it on immediate fast track! ${ }^{\circ}$

The vote was unanimous.

Nancy Kress's most recent novel is Nothing Human, in which the humanrace comes to an end - but not before engineering our genetic descendents. Her fiction has won three Nebula Awards and a Hugo Award. 